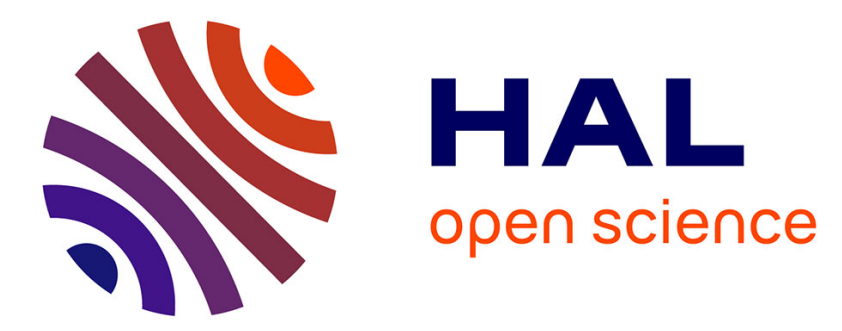

\title{
Geographic patterns in freshwater gammarid invasions: an analysis at the pan-European scale
}

Simon Devin, Jean-Nicolas Beisel

\section{To cite this version:}

Simon Devin, Jean-Nicolas Beisel. Geographic patterns in freshwater gammarid invasions: an analysis at the pan-European scale. Aquatic Sciences - Research Across Boundaries, 2008, 70 (1), pp.100 - 106. 10.1007/s00027-008-8009-1 . hal-01726698

\section{HAL Id: hal-01726698 \\ https://hal.univ-lorraine.fr/hal-01726698}

Submitted on 8 Mar 2018

HAL is a multi-disciplinary open access archive for the deposit and dissemination of scientific research documents, whether they are published or not. The documents may come from teaching and research institutions in France or abroad, or from public or private research centers.
L'archive ouverte pluridisciplinaire HAL, est destinée au dépôt et à la diffusion de documents scientifiques de niveau recherche, publiés ou non, émanant des établissements d'enseignement et de recherche français ou étrangers, des laboratoires publics ou privés. 
1 Geographic patterns in freshwater gammarid invasions: an analysis at

2 the pan-European scale

5 Simon DEVIN ${ }^{*}$ and Jean-Nicolas BEISEL

6 Laboratoire Interactions Ecotoxicologie Biodiversité Ecosystèmes (LIEBE), Université Paul

7 Verlaine - Metz, UMR CNRS 7146

8

9 Address :

10 Univ. Paul Verlaine - Metz, LIEBE Laboratory, UMR CNRS 7146

11 Campus Bridoux, Av. Gén. Delestraint

12 Metz, F-57070

13 FRANCE

14

15 Abbreviated title : Biogeography and invasive gammarids

\footnotetext{
* Corresponding author fax : $+33(0) 387378423$ tel : $+33(0) 387378402$

Email : devin@univ-metz.fr
} 


\section{ABSTRACT}

17 Biogeographic characteristics of freshwater gammarids at a pan-European scale were

18 investigated to describe spatial gradients of richness and their relationships with the pattern of

19 invasive species distribution. Species richness appeared to be linked to latitude and among the 25

20 European biogeographical areas, the Ponto-Caspian basin exhibited a particular position, being

21 by far the most diverse area. A link between the species richness of an area and the number of

22 invasive species coming from this area was observed, showing that rich areas are more prone to

23 shelter potential invaders than others. The patterns of gammarid dispersals among European

24 waterways suggest that, rather than a random distribution of invaders, a clump occurred in basins

25 which served as refuge areas during the last glaciations. Several reasons explaining the pattern

26 are discussed, including the possibility that among species evolving in a stimulating environment

27 some of them have had the opportunity to develop special competitive attributes.

30 Key-words : biological invasions, amphipods, biogeography, species transfers 


\section{INTRODUCTION}

32 Identifying potential invaders generally requires paying attention to the role of the biological and

33 ecological features of invaders in order to draw a general profile of species at risk (Williamson

34 and Fitter, 1996; Kolar and Lodge, 2001). This kind of analysis, already performed for

35 gammarids, revealed the predominant role of ecological traits (Devin and Beisel, 2007). An

36 innovative and complementary method is the investigation of geographic patterns in the

37 distribution of invasive and non-invasive species within a taxonomic group. Such a

38 biogeographical approach has already been adopted for plant invasions, with most of the focus

39 on the differences in species traits according to the donor region, or on differences between

40 native and invasive traits within a region (Pyšek et al., 2004 and references therein). To date, no

41 study has reported how the biotic context of donor areas can enhance their capacity to supply

42 invasive species. Biotic context includes characteristics such as the number of endemic species,

43 the species richness within a clade, and the latitudinal distribution.

44 In Europe, the Ponto-Caspian basin (Black, Azov, and Caspian Seas) has been identified

45 as a donor region for numerous freshwater species now found in Western Europe (bij de Vaate et

46 al., 2002; Devin et al., 2005b) and the North American Great Lakes (Ricciardi and MacIsaac,

47 2000; MacIsaac et al., 2001). The two main causes evoked are the broad salinity tolerance and

48 the potential displacement of Ponto Casopian species via important shipping traffic on several

49 particular routes (MacIsaac et al., 2001). While these two conditions contribute to explain how

50 the first two steps of the invasion process (dispersal and establishment) are completed, they are

51 not sufficient to fully explain the geographical clump of the invader origin area.

Among introduced freshwater species, gammarids constitute a homogenous phylogenetic

53 clade with numerous invaders. In Western Europe, non-indigenous crustaceans have met with 
54 more success than other taxa (Devin et al., 2005b). The ecology of most European gammarid

55 species is well documented with recent studies devoted to the dispersal of invasive species

56 among different European basins (Jazdzewski, 1980; bij de Vaate et al., 2002; van der Velde et

57 al., 2002; Jazdzewski et al., 2004). Thus, amphipod crustaceans constitute an interesting model

58 to analyse mechanisms underlying an invasion process.

59 We investigated several biogeographic characteristics of gammarids to explore the

60 existence of spatial gradients in gammarid richness and to analyse the link between a

61 biogeographic gradient and the pattern of invasive species distribution. These points allowed us

62 to discuss whether common biogeographic features are shared by invasive gammarids and

63 potential evolutionary explanations related to these patterns.

\section{MATERIAL AND METHODS}

\section{Analysis of gammarid distribution at a pan-European scale}

69 The analysis of geographical gradients in Gammaridae distribution at a pan-European scale was

70 based on the 25 biogeographical areas defined by Illies (1978) in Limnofauna Europaea and on

71 information provided in Barnard and Barnard synthesis (1983). The number of fresh and

72 brackish water Gammaridae species within each zone was determined, excluding groundwater

73 species. Species occurring in a unique area (e.g. endemic species) were counted and reported on

74 a map showing the biogeographic areas (Fig. 1). The mean geographic coordinates of each zone

75 were determined by checking those of a point located at the graphically estimated gravity centre 
76 of each area. To simplify the statistical analysis, areas positioned westward of the Greenwich

77 Meridian were noted negatively.

To assess whether latitudinal and longitudinal clines influence species richness in Europe,

79 linear regression analyses of species richness against latitude and longitude were performed.

80 Student t-tests allowed us to assess whether these relationships were significant.

\section{Origin of exotic gammarids}

83 The analysis of geographical origin of invasive gammarids within European freshwaters was also

84 based on the biogeographical zones defined by Illies (1978). Only species of European origin

85 that have moved from at least one area to another were taken into account (i.e. species

86 movements within an area were not considered). Species with a European origin that only moved

87 outside of Europe or those with an extra-European origin that invaded Europe, such as

88 Gammarus tigrinus Sexton, 1939 or Gmelinoides fasciatus Stebbing, 1899, were not considered.

89 Based on the bibliography, a list of 15 gammarid species that have moved in Europe during the

90 last 150 years was established. Once this species list was established, their geographic origin was

91 defined based on the work of Illies (1978). A linear regression between the number of species

92 within a given area and the number of exotic species that came from this area was performed. A

93 student t-test allowed us to assess whether this relationship was significant.

94 Exponential and log-linear models were tested on each scatterplot but the linear regression

95 provided the best fit to the observed data with normally distributed residuals.

\section{Results}


100 When plotting the number of species in each area according to their average latitude, a

101 significant latitudinal gradient appeared (Fig. 2a), showing that species richness decreased

102 significantly $\left(\mathrm{r}_{\text {Pearson }}=-0.50, \mathrm{n}=25, p=0.005\right)$ from south $\left(38^{\circ}\right.$ latitude $)$ to north $\left(69^{\circ}\right.$ latitude $)$ in

103 Europe. Two areas, the Pontian province and the Caspian lowlands, defining the Ponto-Caspian

104 basin, were distinguished by a high number of species (43 and 51, respectively), 30\% higher than

105 the next richest area (Iberian Peninsula with 29 species). Two corrections could be performed on

106 the dataset to validate the legacy of lineage hypothesis between species richness and latitude.

107 First, we excluded the two particular areas evoked to assess how they contribute to the latitudinal

108 gradient. The new Pearson coefficient $\left(\mathrm{r}_{\text {Pearson }}=-0.63, \mathrm{n}=23, p<0.001\right)$ exceeded the value

109 previously obtained with the whole dataset. Second, we weighted the richness by the surface area

110 expressed in natural logarithm (Fig. 2b) and a significant correlation was still observed $\left(\mathrm{r}_{\text {Pearson }}=\right.$

$111-0.52, \mathrm{n}=23, p=0.005)$.

112 The same analyses were performed between species richness and the longitudinal data. A

113 slight but significant gradient was observed $\left(\mathrm{r}_{\text {Pearson }}=0.363, \mathrm{n}=25, p=0.037\right)$, with a small

114 decrease in species number from east $\left(52^{\circ}\right.$ longitude east) to west ( $18^{\circ}$ longitude west).

115 However, when we excluded the Ponto-Caspian area, the pattern was no longer significant,

116 whatever the weight applied to the richness.

117 A correlation between the number of gammarid species in an area and the number of

118 invasive species originating from this area was observed (Fig. 3; $\mathrm{r}_{\text {Pearson }}=0.78, \mathrm{n}=25, p<$

119 0.001), showing that rich areas provide more exotic species than poorly diversified areas. The

120 Ponto-Caspian basin is by far the most important European pool of invasive species.

121 Finally, the mean richness of the donor areas can be analysed versus that of the receptor

122 areas (Fig. 4), showing that invasive species come from areas where the mean richness is higher 
123 than that of the invaded areas (Wilcoxon paired test, $p<0.01$ ). The second panel of this figure

124 shows the same data, but takes into consideration the overlap in species composition by

125 removing, in pairwise region comparisons, species present in both regions. It shows that species

126 composition of donor and receptor areas is independent, with only a few species present in both.

127 Moreover, it confirms that donor areas are richer that receptor areas (Wilcoxon paired test, $p<$

128 0.01). To complete this approach a synthesis of the flux of gammarids in Europe (Fig. 5) was

129 performed based on several articles dealing with amphipod invasions (Jazdzewski, 1980;

130 Arbaciauskas, 2002; bij de Vaate et al., 2002; Nehring, 2002; Slynko et al., 2002; Van der Velde

131 et al., 2002; Jazdzewski et al., 2004; Devin et al., 2005a,b). It allowed us to illustrate that the

132 main invasion corridors are from east to west (Ponto-Caspian basin and Balkans to Western

133 Europe) and from south to north (Pyrenees to Northern France, Western continental Europe to

134 Ireland, Ponto-Caspian basin to Northern Europe).

\section{DISCUSSION}

137 We found a negative correlation between species number and latitude, a robust pattern in 138 biogeography seen in the great majority of taxonomic groups (Blondel, 2000; Sax, 2001). As a 139 result, species richness decreases from south to north. Many explanations have been proposed to 140 elucidate the origins of this gradient (Blondel, 2000); a preponderant role in recent theories gives

141 to biotic interactions as the factor that regulates diversity (France, 1992). In Europe, this decrease

142 in species richness of freshwater gammarids could be linked to recent geological history of the

143 continent. During the Würm glaciation (80,000-10,000 BP), a major part of Western Europe was

144 covered by ice or in a permafrost state. Thus, at the end of this period, defaunated freshwater

145 ecosystems appeared that were recolonised by fish species that survived in refuge areas that were 
146 outside of the range of ice extension (according to Oberdorff et al., 1997). The same mechanism

147 of recolonisation of defaunated ecosystems from refuge areas also occurred for

148 macroinvertebrates in Europe and in North America (France, 1992; Vainio and Väinölä, 2003).

149 The two main refuge areas in Europe were Mediterranean Europe and the Danube basin (Persat 150 and Keith, 1997). Each played a key role of a 'living museum' during the glacial periods and

151 thus explains the species gradient observed by the number of endemic species in each area (Fig. $1521)$.

153 The Ponto-Caspian basin fits with the geographical gradient found, but is remarkable for 154 being by far the richest area in Europe for gammarid species. Remnants of the intracontinental 155 Paratethys basin, an area home to a spectacular radiation of crustaceans (Cristescu et al., 2003), 156 led Zenkevich (1963) to propose that the Caspian Sea should be called the 'Crustacean Sea'. In 157 the Caspian Sea, adaptive radiation has occurred in many groups and endemisms at the species 158 level often reach $80 \%$ (Dumont, 2000). Endemism is so important that it rivals that of Lake 159 Baikal, where about 300 gammarid species occurred (France, 1992; Dumont, 2000) as a result of 160 a long evolutionary history without a glaciation period. The Ponto-Caspian basin is the most 161 frequent donor basin implied in freshwater invasions by gammarids as well as several other taxa 162 (Ricciardi and Macisaac, 2000; bij de Vaate et al., 2002; Reid and Orlova, 2002; Devin et al., 163 2005b). We can therefore wonder whether the species diversity of a basin favours the emergence 164 of invasive species. The correlation between the gammarid species richness of an area and 165 invasive gammarids coming from this area confirms that invasive European gammarid species 166 underwent the majority of their evolution in areas rich in closely-related species. Nevertheless, 167 five areas exhibited particular results, and have provided few invasive gammarids to other 168 European areas compared to their richness: the Western lowlands, Iberian Peninsula, Italy, 
169 Dinarian, and Hellenic Western Balkans. The low number of invaders coming from the last four

170 areas could easily be explained by their strong geographic isolation, having a low connectivity

171 with the main European waterways.

$172 \quad$ From a probabilistic approach, if invasive species are distributed randomly among

173 ecological areas, a larger pool of species is more likely to become invasive in highly diversified

174 area than in areas with a low number of species. Nevertheless, if a species has a broad

175 distribution range in its natural habitat area, co-occurring with many other closely-related species

176 and exploiting a broad spectrum of resources, this species possesses the attributes needed to

177 establish itself more surely in a recipient ecosystem than a specialized species narrowly

178 distributed and poorly adapted to competition. Thus, evolving in a species-rich area can lead to

179 selection, within a pool of species, for some species to acquire the attributes needed to compete

180 efficiently. This particular profile could be useful to spread among non-naïve ecosystems already

181 sheltering closely related species, while the profile of invaders will be less important for success

182 in a naïve ecosystem.

183 Our results alone did not allow us to fully determine whether the invader origins are

184 randomly distributed or related to particular competitive abilities developed in species-rich areas.

185 Our results support that invasive species come from areas where the mean richness is higher than

186 that of invaded areas. The synthesis of gammarid dispersals in Europe (Fig. 5) highlighted that

187 the main invasion corridors are unidirectional from east to west and from south to north. This

188 suggests that species invaded areas with a lower diversity, thus with a lower competition, than

189 the donor basin or, to keep the same terminology, that the recipient ecosystem is more naïve than

190 the donor. However, this pattern could be linked to asymmetrical species transfers due to current

191 trade patterns (Ricciardi and MacIsaac, 2000). 
We postulate that an environment with rich, complex assemblages of closely-related

195 species evolving in their natural range is more likely to favour the emergence of potential

196 invasive species. This hypothesis does not link invasiveness to species biological/ecological

197 characteristics directly, but contributes to an understanding of reasons allowing some species to

198 be more successful than others. We focused on the innovative assumption that species evolving

199 in areas with a high number of closely-related species (from a taxonomic point of view) leads to

200 selection for a set of species developing their competitive potential. This implies that such

201 ecological areas would be more frequently identified as the native region of successfully

202 introduced species. These areas are, more extensively, the cradles of potential exotic species

203 even if the mechanism shaping these species is unknown. In particular, the lack of phylogeny at a

204 large scale for European species did not allow us to test either the hypothesis of a common

205 ancestor with singular competitive features or the phylogenetic relatedness to the native

206 community (Darwin's naturalisation hypothesis).

207 From an evolutionist point of view, it can seem paradoxical that a species introduced into

208 a new ecosystem is a better competitor than an autochthonous species having evolved in that

209 same ecosystem. Sax and Brown (2000) proposed two patterns to demonstrate the logic of this

210 situation. The first pattern is explained by an exotic species' pre-adaptation for altered

211 environments and opportunities created by an absence of enemies (Keane and Crawley, 2002).

212 The most invaded ecosystems, such as the Rhine River (Den Hartog et al., 1992) or San

213 Francisco Bay (Cohen and Carlton, 1998), are generally disturbed environments suffering high

214 levels of anthropogenic stress. In most estuaries and large rivers, autochthonous relic species are 
215 poorly adapted, lagging behind in their evolution while their environment has continued to

216 change quickly over the last century. Due to this evolutionary anachronism, introduced species in

217 a disturbed ecosystem can easily become the best competitors. A second pattern proposed by Sax

218 and Brown (2000) is that introduced species can benefit from environmental stochasticity and a

219 global release of introduced species from pressure due to competitors, predators, parasites and

220 diseases. This view can be completed with two supplementary elements related to biogeography:

221 the positive interaction between introduced species from the same area of origin (suggested in

222 the invasional meltdown hypothesis proposed by Simberloff and Von Holle, 1999; Simberloff,

223 2006) and the advantages due to the biogeographical origin of invaders (already evoked by Sax

224 and Brown, 2000). According to our results, a species' biogeographical origin can confer a

225 particularly high potential upon it for being a competitor. A few species in a rich area could be

226 pre-adapted to compete successfully with closely-related species with different profiles (a

227 'biogeographic bonus'). As an example, a recent article (Kelly et al., 2006) described the

228 alteration of native communities by the invasive amphipod Gammarus pulex in Ireland. Among

229 the different mechanisms evoked, a better acquisition and assimilation of resources by the

230 invasive species than by the native G. duebeni celticus suggest that competition could have

231 driven the regression of the latter. Moreover, a complementary explanation might be found in the

232 fact that facilitation relationships can increase the invasion success of a group of species having

233 co-evolved in the same donor ecosystem. These positive interactions among invading species

234 have been found to be more common than previously assumed for the North American Great

235 Lakes (Ricciardi, 2001). Hence, biogeographical features such as species traits should be used in

236 the general framework of invader predictions to identify species at risk within regions at risk. 
238 Finally, our results are in accordance with the hypothesis that the evolutionary context is an

239 element to consider as determinant to select special features of invaders, while alternative

240 explanations could be advanced (asymmetrical species transfer and random distribution of

241 invaders). The way a species evolves in a rich biota, in terms of closely-related species, needs to

242 be further investigated, to test the validity of the 'biogeographic bonus' hypothesis.

\section{ACKNOWLEDGEMENTS}

246 This study is supported by the French 'Ministère de l'Ecologie et du Développement Durable', 247 as part of the INVABIO - Biological Invasions 2003-2005 program. We thank Dov Sax for 248 helpful comments on an earlier version of the manuscript.

\section{BIBLIOGRAPHY}

Arbaciauskas, K., 2002. Ponto-Caspian amphipods and mysids in the inland waters of Lithuania:

254 History of introduction, current distribution and relations with native malacostracans. In: E.

255 Leppäkoski, S. Gollasch, and S. Olenin (eds), Invasive aquatic species of Europe. Distribution, 256 impacts and management. Kluwer Academic Publishers, Dordrecht, pp 104-115.

257 Barnard, J.L. and C. M. Barnard, 1983. Freshwater Amphipoda of the world (2 volumes).

258 Hayfield Associates, Virginia, 717 pp.

259 bij de Vaate, A., K. Jazdzewski, H. A. M. Ketelaars, S. Gollasch, and G. van der Velde, 2002.

260 Geographical patterns in range extension of Ponto-Caspian macroinvertebrate species in Europe.

261 Canadian Journal of Fisheries and Aquatic Sciences 59: 1159-1174. 
262 Blondel, J., 2000. Biogéographie. Approche écologique et évolutive. Masson, Paris.

263 Cohen, A. N., and J. T. Carlton, 1998. Accelerating invasion rate in a highly invaded estuary.

264 Science 279: 555-558.

265 Cristescu, M. E. A., P. D. N. Hebert, and T. M. Onciu, 2003. Phylogeography of Ponto-Caspian 266 crustaceans: a benthic-planktonic comparison. Molecular Ecology 12: 985-996.

267 Den Hartog, C., F. W. B. Brink and G., van der Velde, 1992. Why was the invasion of the river 268 Rhine by Corophium curvispinum and Corbicula species so successful? Journal of Natural 269 History 26: 1121-1129.

270 Devin, S., J.-N. Beisel, P. Usseglio-Polatera, and J.-C. Moreteau, 2005a. Changes in functional 271 biodiversity in an invaded freshwater ecosystem: the Moselle River. Hydrobiologia 542: 113272120.

273 Devin, S., L. Bollache, P.-Y. Noël, and J.-N. Beisel, 2005b. Patterns of biological invasions in 274 French freshwater systems by non-indigenous macroinvertebrates. Hydrobiologia 551: 137-146.

275 Devin, S. and J.-N. Beisel, 2007. Biological and ecological characteristics of invasive species: a 276 gammarid study. Biological Invasions 9: 13-24.

277 Dumont H.J., 2000. Endemism in the Ponto-Caspian fauna, with special emphasis on the 278 Onychopoda (Crustacea). In: A. Rossiter and H. Kawanabe (eds), Advances in ecological 279 research. Ancient lakes: biodiversity, ecology and evolution. Academic Press, San Diego, pp. 280 181-196.

281 France, R., 1992. The North American latitudinal gradient in species richness and geographical 282 range of freshwater crayfish and amphipods. The American Naturalist 139: 342-354.

283 Illies, J., 1978. Limnofauna Europaea. G. Fischer Verlag, Stuttgart, 532 pp. 
284 Jazdzewski, K., 1980. Range extension of some Gammaridean species in European inland

285 waters caused by human activity. Crutaceana Suppl. 6: 84-107.

286 Jazdzewski, K., A. Konopacka, and M. Grabowski, 2004. Recent drastic changes in the

287 gammarid fauna (Crustacea, Amphipoda) of the Vistula River deltaic system in Poland caused by

288 alien invaders. Diversity and Distributions 10: 81-87.

289 Keane, R. M., and M. J. Crawley, 2002. Exotic plant invasions and the enemy release

290 hypothesis. Trends in Ecology and Evolution 17: 164-170.

291 Kelly, D. W., R. A. Bailey, C. MacNeil, J. T. A. Dick and R. A. McDonald, 2006. Invasion by

292 the amphipod Gammarus pulex alters community composition of native freshwater

293 macroinvertebrates. Diversity and Distributions 12: 525-534.

294 Kolar, C. S., and D. M. Lodge, 2001. Progress in invasion biology: predicting invaders. Trends 295 in Ecology and Evolution 16: 199-204.

296 MacIsaac, H. J., I. A. Grigorovich, and A. Ricciardi, 2001. Reassessment of species invasions

297 concept: the Great Lakes basin as a model. Biological Invasions 3: 405-416.

298 Nehring, S, 2002. Biological invasions into German waters: an evaluation of the importance of 299 different human-mediated vectors for nonindigenous macrozoobenthic species. In: E.

300 Leppäkoski, S. Gollasch, and S. Olenin (eds), Invasive aquatic species of Europe. Distribution, 301 impacts and management. Kluwer Academic Publishers, Dordrecht, pp 373-383.

302 Oberdorff, T., B. Hugueny, and J. F. Guégan, 1997. Is there an influence of historical events on 303 contemporary fish species richness in rivers? Comparisons between Western Europe and North 304 America. Journal of Biogeography 24: 461-467. 
305 Persat, H., and P. Keith, 1997. La répartition géographique des poissons d'eau douce en France:

306 qui est autochtone et qui ne l'est pas? Bulletin Français de la Pêche et de la Pisciculture 344/345:

$307 \quad 15-32$.

308 Pyšek, P., D. M. Richardson, and M. Williamson, 2004. Predicting and explaining plant

309 invasions through analysis of source area floras: some critical considerations. Diversity and

310 Distributions 10: 179-187.

311 Reid, D. F., and M. I. Orlova, 2002. Geological and evolutionary underpinnings for the success

312 of Ponto-Caspian species invasions in the Baltic Sea and North American Great Lakes.

313 Canadian Journal of Fisheries and Aquatic Sciences 59: 1144-1158.

314 Ricciardi, A, 2001. Facilitative interactions among aquatic invaders: is an "invasional

315 meltdown" occurring in the Great Lakes? Canadian Journal of Fisheries and Aquatic Sciences

316 58: 2513-2525.

317 Ricciardi, A., and H. J. MacIsaac, 2000. Recent mass invasion of the North American Great

318 Lakes by Ponto-Caspian species. Trends in Ecology and Evolution 15: 62-65.

319 Sax, D. F., 2001. Latitudinal gradients and geographic ranges of exotic species: implications for 320 biogeography. Journal of Biogeography 28: 139-150.

321 Sax, D. F., and J. H. Brown, 2000. The paradox of invasion. Global Ecology and Biogeography 322 9: $363-371$.

323 Simberloff, D., and B. Von Holle, 1999. Positive interactions of nonindigenous species:

324 invasional meltdown? Biological Invasions 1: 21-32.

325 Simberloff, D., 2006. Invasional meltdown 6 years later: important phenomenon, unfortunate 326 metaphor, or both? Ecology Letters 9(8): 912-919. 
327 Slynko, Y. V., L. G. Korneva, I. K. Rivier, V. G. Papchenkov, G. H. Scherbina, M. I. Orlova, 328 and T. W. Therriault, 2002. The Caspian-Volga-Baltic invasion corridor. In: E. Leppäkoski, S.

329 Gollasch, and S. Olenin (eds), Invasive aquatic species of Europe. Distribution, impacts and

330 management. Kluwer Academic Publishers, Dordrecht, pp. 399-411.

331 van der Velde, G., I. Nagelkerken, S. Rajagopal, and A. bij de Vaate, 2002. Invasions by alien

332 species in inland freshwater bodies in western Europe: The Rhine Delta. In: E. Leppäkoski, S.

333 Gollasch, and S. Olenin (eds), Invasive aquatic species of Europe. Distribution, impacts and

334 management. Kluwer Academic Publishers, Dordrecht, pp360-372.

335 Vainio J.K. and R. Väinölä, 2003. Refugial races and postaglacial colonization history of the

336 freshwater amphipod Gammarus lacustris in Northern Europe. Biological Journal of the Linnean

337 Society 79: 523-542.

338 Williamson, M. H., and A. Fitter, 1996. The characters of successfull invaders. Biological

339 Conservation 78: 163-170.

340 Zenkevich, L., 1963. Biology of the Seas of the USSR. George Allen and Unwin, London; 956 341 pp. 


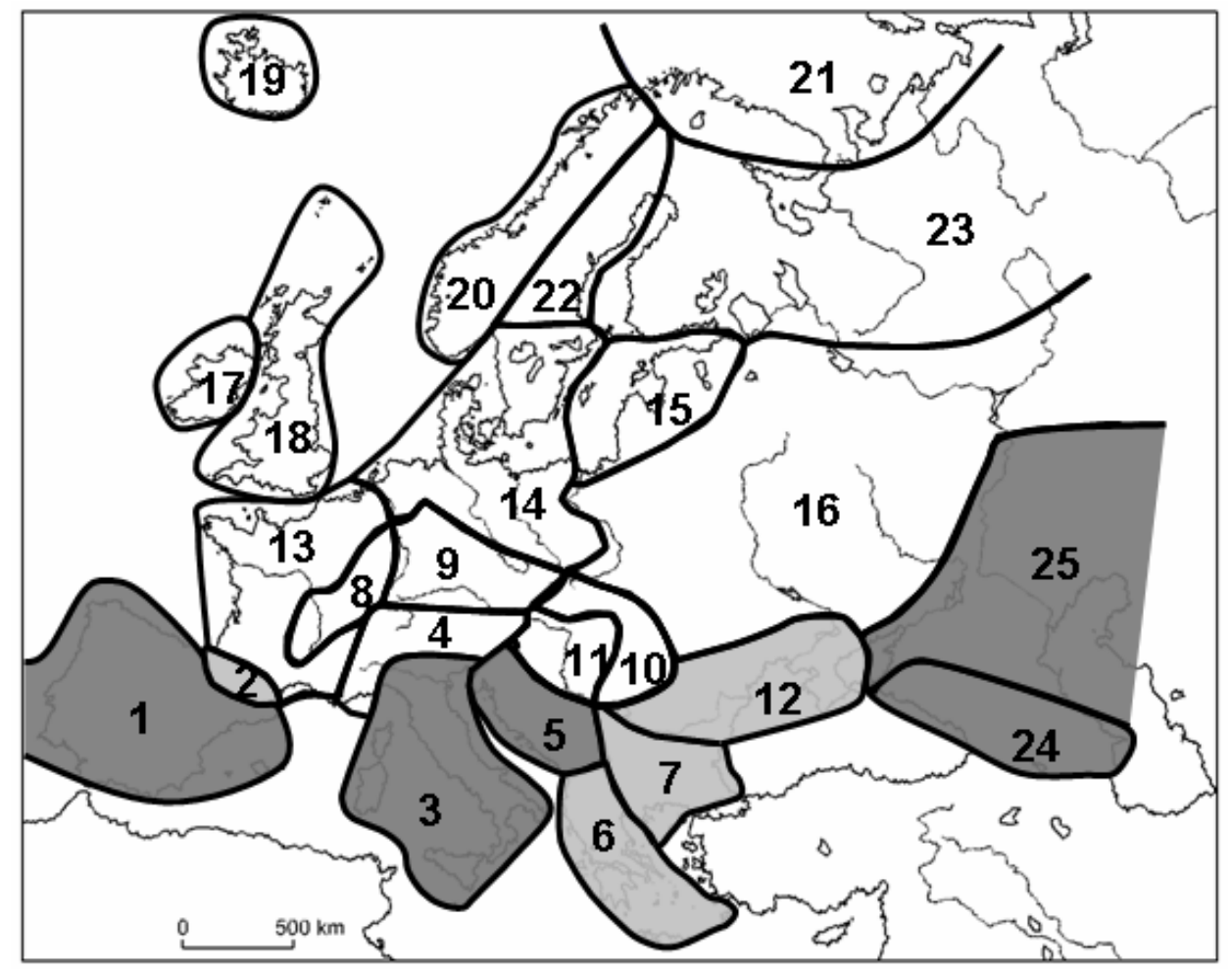

Number of endemic gammarids

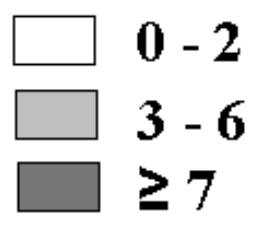

Figure 1: Map of the 25 European biogeographical areas, redrawn after Illies (1978). Shaded areas represent the number of endemics.

1: Iberian Peninsula - 2: Pyrenees - 3: Italy - 4: Alps - 5: Dianarian Westen Balkans - 6: Hellenic Western Balkans - 7: Eastern Balkans - 8: Western Sub-alpine mountains - 9: Central Sub-alpine mountains - 10: Carpathian - 11: Hungarian Plain - 12: Pontian Province - 13: Western Lowlands - 14: Central Lowlands - 15: Baltic Province - 16: Eastern Lowlands - 17: Ireland - 18: England - 19: Iceland - 20: Boreal Highlands - 21: Tundra - 22: Northern Sweden 23: Taiga - 24: Caucasus - 25: Caspian Lowlands.

Figure 2: Gradients of gammarid species number among the 25 biogeographical areas of Illies (1978) according to their mean latitude. (a) Raw data and (b) richness weighted by the natural logarithm of the surface area, with the exclusion of the Pontian province and Caspian lowlands. Figure 2: Gradients of gammarid species number among the 25 biogeographical areas of Illies (1978) according to their mean latitude. (a) Raw data and (b) richness weighted by the natural logarithm of the surface area, with the exclusion of the Pontian province and Caspian lowlands. 
a

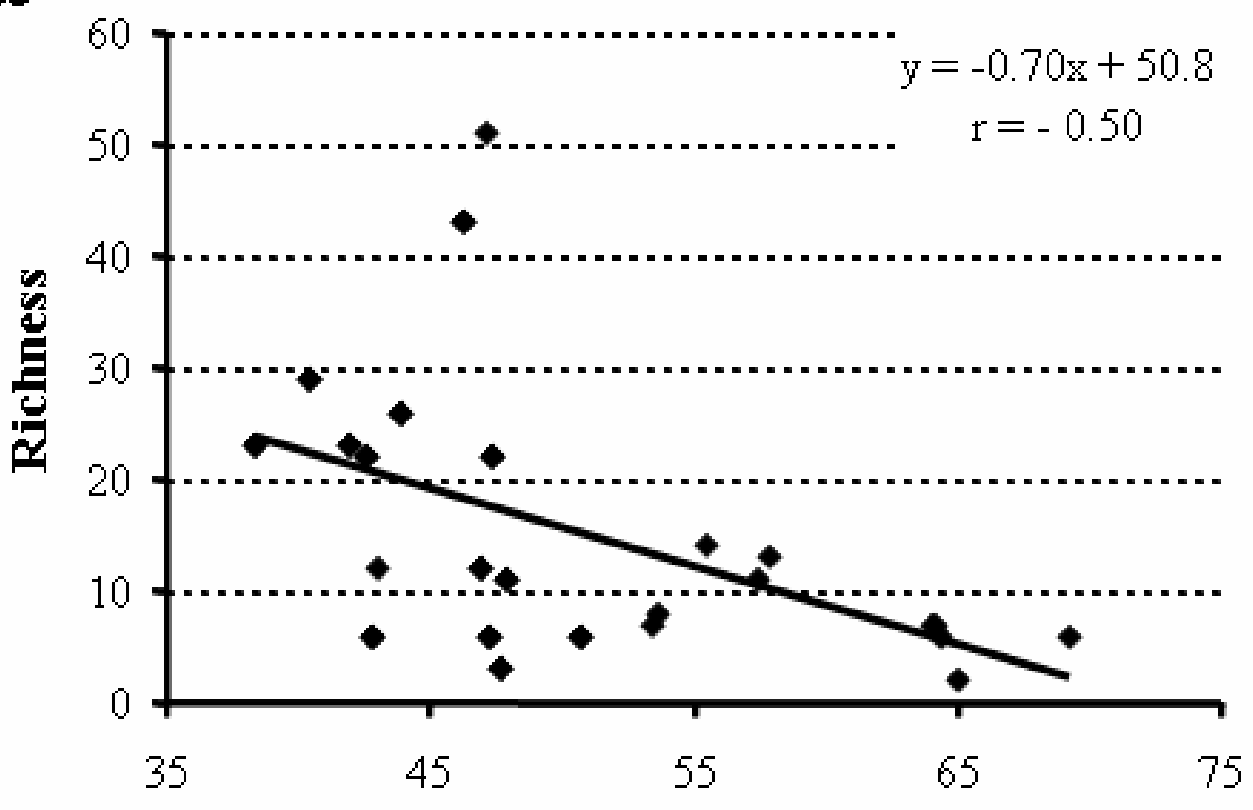

b

\section{Latitude}

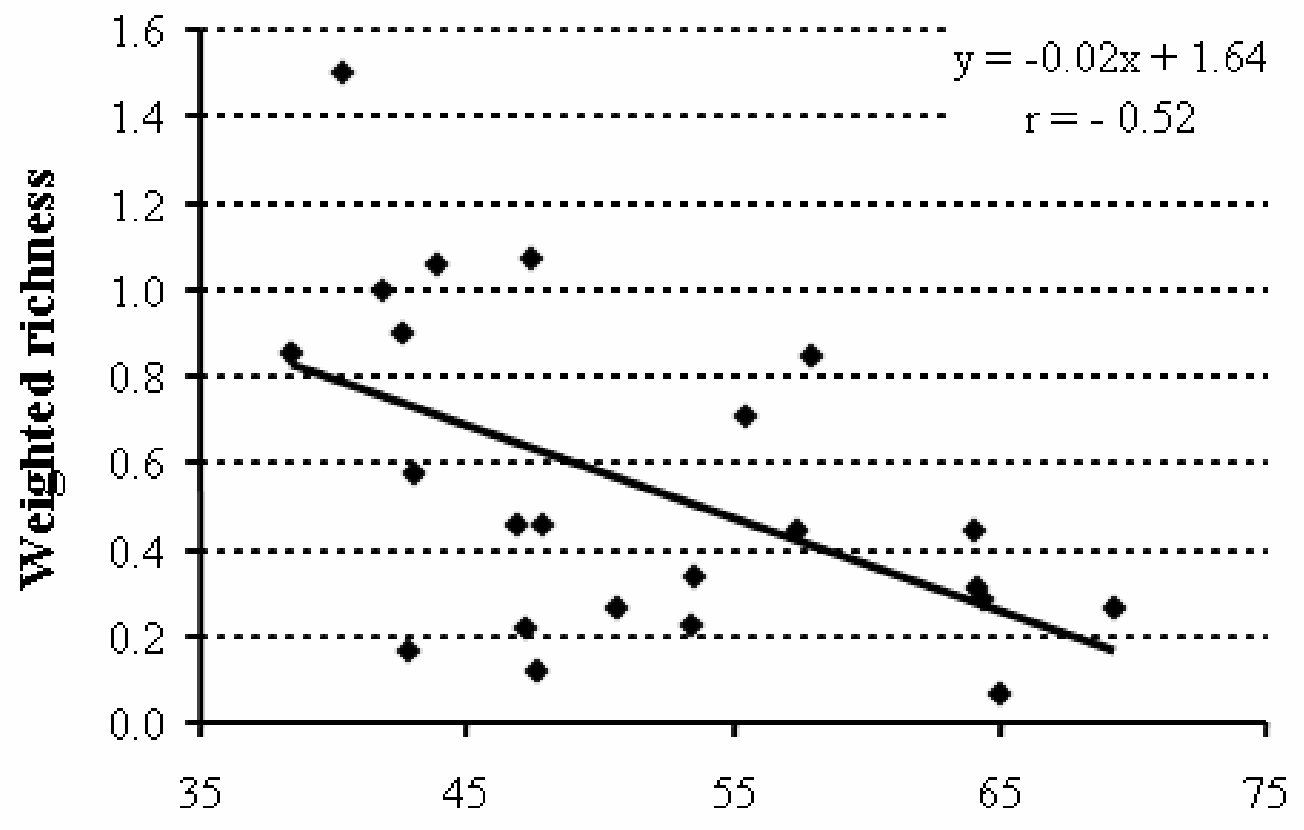

\section{Latitude}

361 Figure 2: Gradients of gammarid species number among the 25 biogeographical areas of Illies

362 (1978) according to their mean latitude. (a) Raw data and (b) richness weighted by the natural

363 logarithm of the surface area, with the exclusion of the Pontian province and Caspian lowlands. 

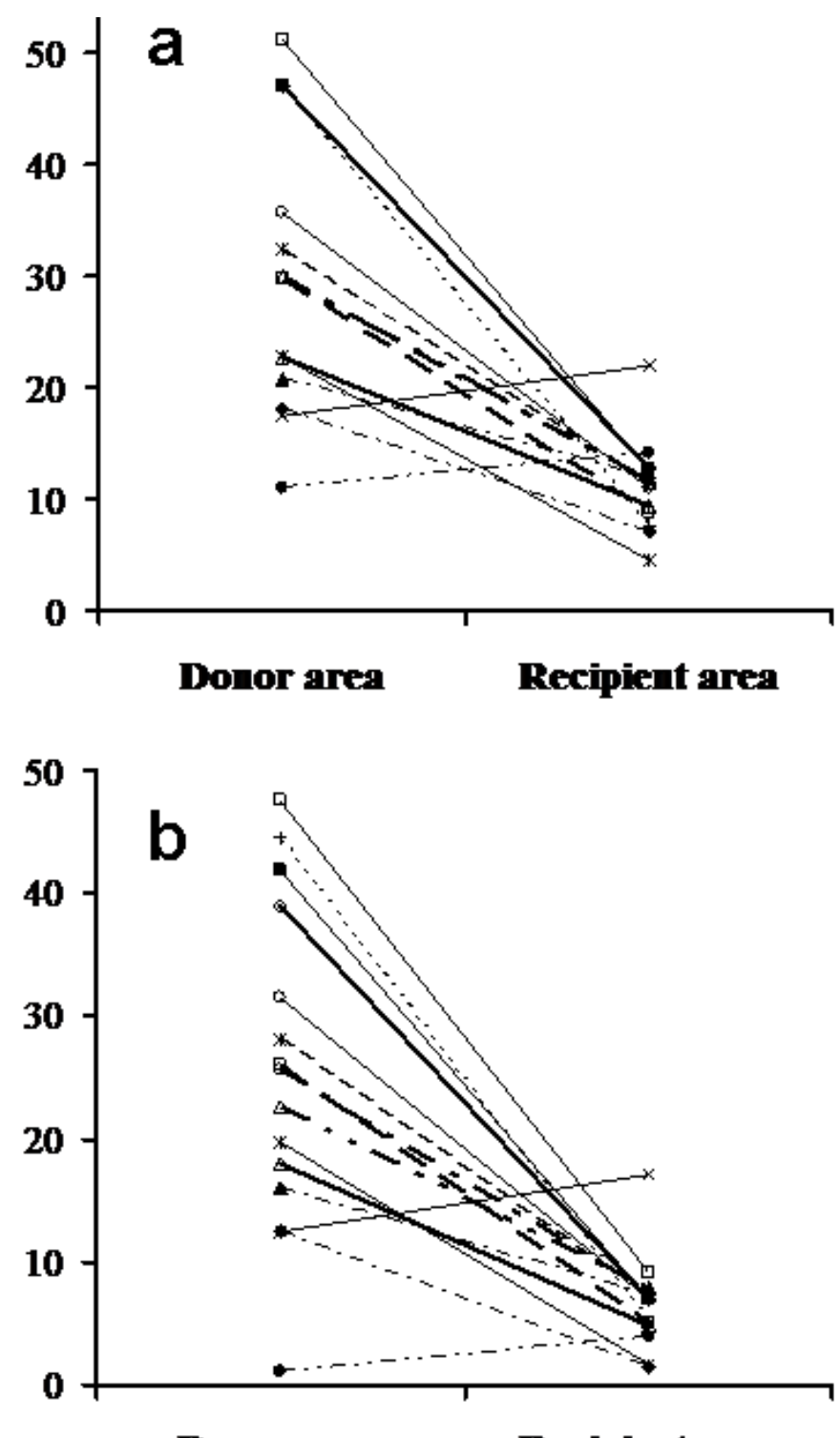

\section{Donor area Recipient area}

$\longrightarrow$ A. cristata $\quad \square-D$. bispinosus $\quad-\Delta-D$. haemobaphes

-a-D. villosus $\rightarrow$-E. berilloni $-*-E$ ischnus

$\cdots+\cdots$ E. trichiatus $\longrightarrow$ E. warpachowskyi $\longrightarrow$ P. robustoides

$-\cdot-G$. pulex $\quad-\cdot \cdot-G$. roeseli $\quad-\cdot-\cdot$ G. varsoviensis

Figure 3: Relationship linking the total number of gammarid species in an area to the number of 


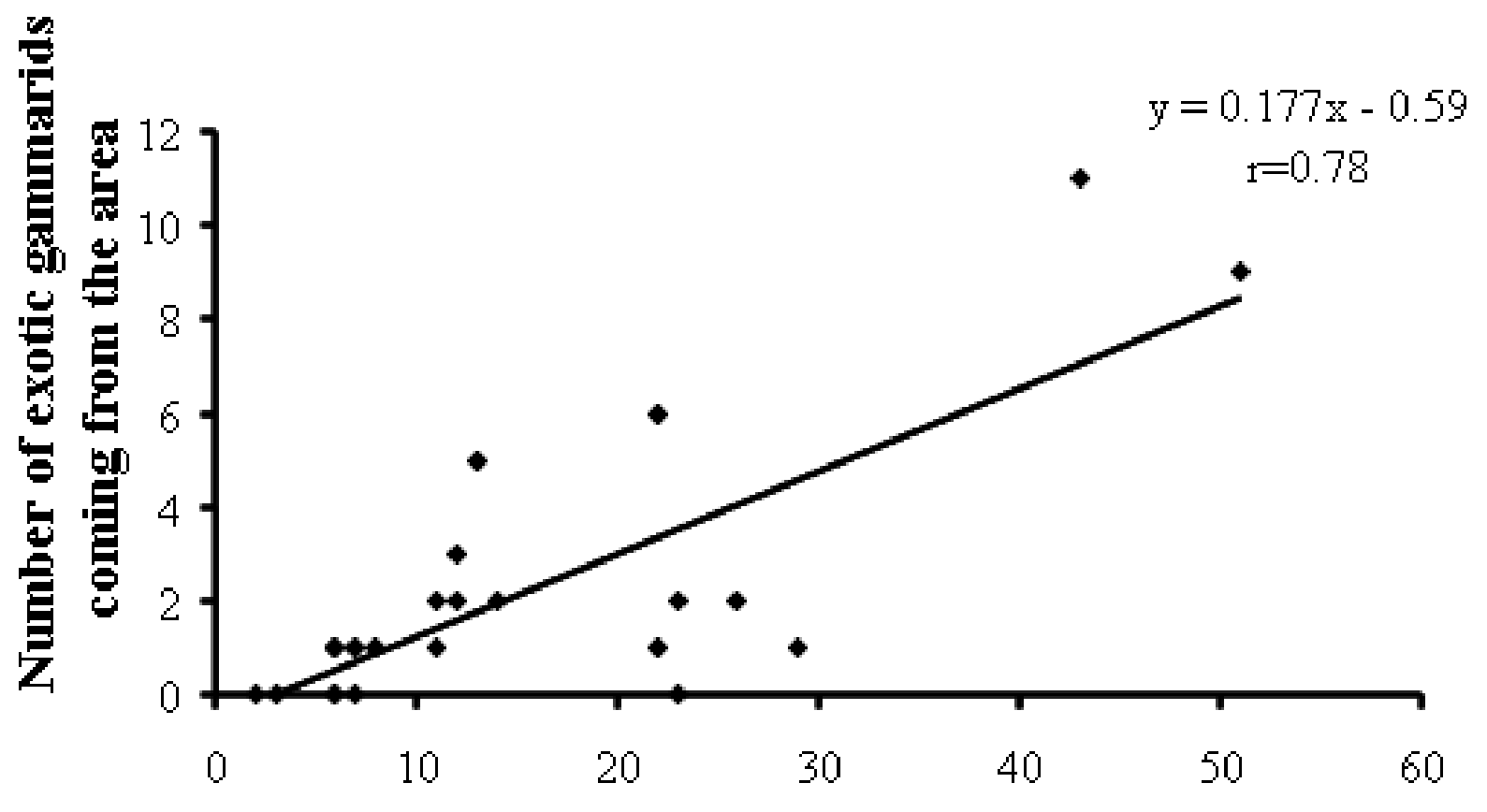

\section{Richness of the area}

370 Figure 4: Mean richness of the donor and receptor areas for the 15 gammarid species that moved 371 inside Europe. (a) Raw data. D. haemobaphes and D. villosus curves are merged, as well as those 372 for E. warpachowski and A. cristata (b) species richness once species present in both donor and 373 recipient areas were removed. 


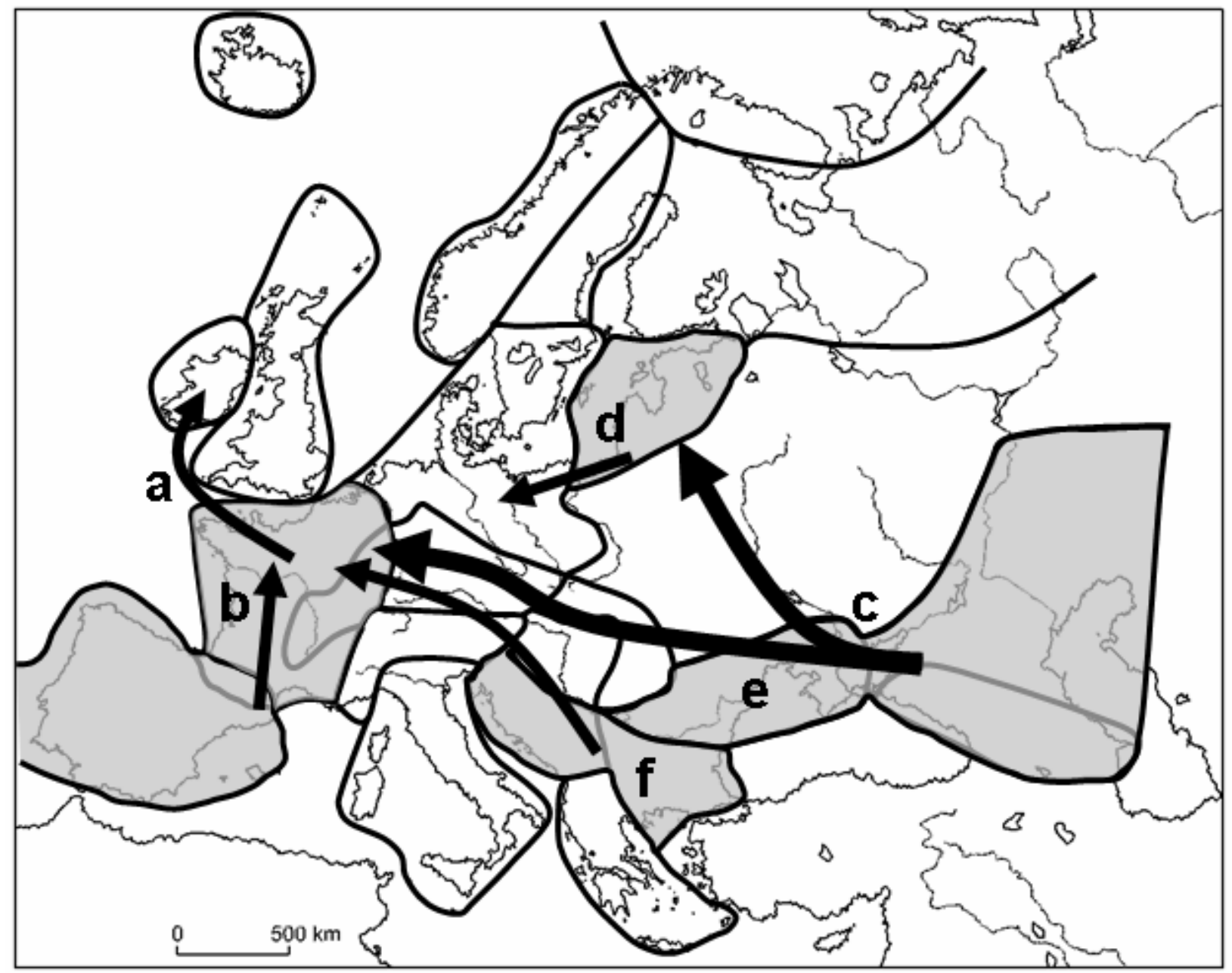

Figure 5: Main flux of gammarid species in Europe according to a bibliographic review (see text for references and Barnard and Barnard 1983 for species authorities). South - North transfers. a: Gammarus pulex; b: Echinogammarus berilloni; c: Amathillina cristata, Dikerogammarus haemobaphes, D. villosus, E. ischnus, E. warpachowskyi, Obesogammarus crassus, Pontogammarus robustoides, Stenogammarus deminutus. East - West transfers. d: Gammarus varsoviensis; e: Dikerogammarus haemobaphes, D. villosus, D. bispinosus, Echinogammarus ischnus, E. trichiatus, E. warpachowskyi, Obesogammarus crassus, O. obesus, Pontogammarus robustoides; f: Gammarus roeseli. 